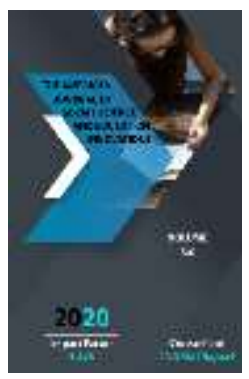

\title{
National Appearances In Tongue Twisters
}

\author{
Inamjan Batirbaevich Madiyarov
}

PhD student Andijan State University, Uzbekistan

Journal Website:

http://usajournalshub.c

om/index,php/tajssei

Copyright: Original

content from this work

may be used under the

terms of the creative

commons attributes

4.0 licence.

\section{ABSTRACT}

The article examines the ancient and rich values of the Uzbek, Karakalpak, Kazakh and Kyrgyz peoples, their national identity, lifestyle and activities that are passed down from generation to generation.

\section{KEYWORDS}

Epic, fairy tale, proverb, riddle, parallelism, animation.

\section{INTRODUCTION}

There is no nation in the world whose national identity is not manifested in its language, literature, art, and spirituality. The works of folklore are one of the main members of our national spirituality, reflecting the history, social life, ancient traditions and customs of the people. The priceless values of the Turkic peoples, polished for thousands of years, imbued with the spirit of nationalism, nourished by the rich life experiences of our ancestors, are reflected in the folklore. In particular, the Uzbek, Karakalpak, Kazakh and Kyrgyz nations are among the Turkic peoples with such rich and ancient values.
"Primitive people expressed their opinions orally at a time when they did not yet know writing. It was at this point that their oral art emerged"'[1. 5]. So, folklore has always been a part of life, living in harmony with the people. Therefore, "Folklore works deeply reflect the traditions and customs of the people."[1.14].

\section{THE MAIN FINDINGS AND RESULTS}

Oral works are varied and contain a large national and spiritual heritage. For example, from large-scale works such as epics, fairy tales to small genres such as proverbs, riddles, 
it reflects the high qualities of the past of the people, social and political life, heroism, wisdom, responsiveness.

We often see quick speech as a means of cultivating speech and giving aesthetic pleasure. If we pay attention, we will see that fast speech as a genre of folklore covers various aspects of nature, humanity and social life. In particular, the activities of the Turkic peoples, such as hunting, animal husbandry, farming, fishing, handicrafts, colorful customs and rituals, are reflected in the examples of rapid expression of these peoples. For example:

Lola allalaydi, Sobir arralaydi [2.174].

Alla is an ancient song that is usually performed from the time a child is born until the age of three or four, and is mostly sung by the child's mother, grandmother, aunt, or sister. In this example, despite the fact that Lola is a young girl, she knows how to say "mother's song" - alla, and Sobir is sawing wood to heat the house and cook. Here the national-philosophical content is reflected in the intercession of Lola and Sobir. Our ancestors have long taught a girl to cook, bake, milk a cow, light a stove, sew and raise children, while a boy has been taught to cut firewood, ride horses, slaughter cattle, and farm and raise livestock and handicrafts. It is known that in ancient times the Turks used to try to cut firewood for the groom. The physical strength itself is lacking for splitting wood. Because wood does not crack where the ax strikes, it takes experience and intelligence to find the place where it will split. In the tongue twister there is a reference to an ancient tradition inherited from our ancestors. In short, the issues of preparing children for marriage, the various trials of life, teaching them to work, as well as the continuation of ancient traditions and customs, are clearly expressed.

It is known that in the past there were no techniques for heavy work, construction, digging, harvesting, in general, all the work was done by hashar (most people work together for free):

Bashar hasharga shoshar,

Yashnar hasharda Bashardan oshar [3. 70].

Hashar is a national exercise, which is carried out by the hands of the majority and the will of the people, embodying the unity of the people. Usually on the day of hashar, the person who performed hashar prepared a large table for the hashar and gave food two or three times. The reason for this is, firstly, the hospitality of the Uzbeks, and secondly, the productivity of work is associated with food, and on such days, mainly the Uzbek national dish osh (pilav) is cooked. The following example also shows the idea of building a house with hashar and then eating soup:

Uy yasashasizmi?

Osh oshasasizmi? [4. 203]

Another example:

Non yasashasizmi, sholi sanashasizmi?[2. 173]

In our opinion, this tongue twister was created in connection with family ceremonies. Making bread in the tongue twister is a prewedding baking ritual in Turkish peoples, counting rice is related to picking up the rice in it before putting the rice in the pilov.

In the subsequent period, certain changes took place in the civilization of the Turkic peoples, whose ethnogenesis is rooted in one root, in connection with their geographical location, lifestyle, and occupation. In particular, the Karakalpaks were mainly engaged in hunting, cattle breeding and 
farming. Also, because they live in the lower reaches of the Amu Darya and around the Aral Sea, fishing is well developed:

Balıq awda,

Aw suwda, Suw kólde?

Kól jerde [5. 445].

Fish has long been revered as a sacred creature for Turkic peoples. The role and value of fish, especially in the life of Karakalpaks, is fragmentary. Fish is a favorite and staple food of the Karakalpaks and is one of the seven treasures. The quoted statement reflects the vital fact that land and water are the source of life for all living things, that there is water for the existence of the earth, and that there is life for the existence of water.

Áńshılar izlesti, Dúz kezdi, iz kesti [5. 455].

Hunting was the main source of livelihood for primitive people. Initially, man learned to hunt and make a living from it. The tongue twister above describes the process of hunting: hunters search for them through the footprints of a hunting animal or bird.

Among the Turkic-speaking nations, the Karakalpaks are distinguished by their hospitality. This habit is confirmed in the following example:

Dástúrxan jayıw, Nandı ortaǵa qoyıw, Hám awız tiyiw, Dástúr deydi.

Sonıń ushın nan jeydi [5. 445].

Each nation has its own unique customs, and for such special customs it acquires nationality. One of the ancient values of the Karakalpak people is the tradition of tasting bread and salt. Usually, when a guest comes to the house, a table is set and bread is placed in the middle, and the guest must taste the bread even if he is in a hurry. Even when women are baking bread, people passing by are invited to eat bread. In Karakalpakstan, not tasting salt from bread is considered disrespectful to homeowners or bakers.

The role of adults in the creation and development of the Tongue twister is significant. But the contribution of children in this process does not lag behind them. Therefore, it is inevitable that the world of children will be revealed in their quick words: their thoughts, lifestyle, daily activities:

Mektepte teppek oynadıq, Teppekti mektepte oynadıq [5.444].

This tongue twister is about one of the Karakalpak folk children's games "teppek". The term "teppek", in our opinion, is derived from the addition of the verb -moq to the verb tep. There are several types of this game where children draw various marked shapes in the form of circles or rectangles using sticks on the ground. Then slate or glass fragments and similar items are thrown into the rectangles, pushed with the foot and transferred to the next cell, and so the game continues.

In ancient times, the Kazakh people lived as nomads and were mainly engaged in animal husbandry. Therefore, in the Kazakh language, the situation with animal husbandry occupies a significant place. This is confirmed by the views of A.T Akjolova: "If we look at folk tongue twisters, from its inner content it skillfully describes the way of life of our ancestors, the way of life, in short waysAlso, since the previous occupation of our people was cattle breeding, tongue twisters related to four cattle (horse, camel, cow, sheep) are also in the majority." [6.45]:

Ozg'an sál aldi,

Báygeni shal aldi.

Shal áli áldi [7. 24]. 
In this example, it is said that the old man was the first to reach the finish line with a slight difference in the horse race, and although the old man was old, he was still ahead, that is, he was faster than the others. Horse racing is one of the ancient national values of the Turkic peoples. In particular, the horse race is highly valued among the Kazakhs, and every year a special race is organized on the occasion of the formation of a special "Golden Tulpor", as well as the "Kazakh Khanate", Independence Day and other weddings. There are "Alaman báyge”, “Tay jaris”, “Qunan jaris”, “Dónen jaris", "Jorg'a jaris" and other rounds of fire racing in Kazakhstan [16]. Horse racing has long existed in Uzbek, Karakalpak and Kyrgyz. This is confirmed by the horse races in the Uzbek epics "Alpomish", Karakalpaks "Alpams" and Kyrgyz "Manas". In Karakalpakstan, such races as "At shabis", "Tay shabis", "Jorg'a shabis", and in Kyrgyz, "Alaman bayge" [17] are held at public holidays and weddings.

The lifestyle and livelihood of the Kazakhs are closely linked to the camel. This is why examples of quick sayings about camels are also common:

Lek-lek ylek keldi, Kóp ylek tylep keldi [8. 51].

Typically, camel hair is torn or sheared during shedding. Camel hair is valuable and is used in sewing warm clothes, bedding, and various household items. In addition, camel meat is a favorite food, especially milk is a cure for various ailments. In addition, the camel is resistant to both heat and cold, droughtresistant, and can walk comfortably in sandy soils. Camels acted as the main load-bearing animals when herders moved to new pastures as soon as the grass ran out.
In Kazakhstan, there are many sayings about cows and sheep, which are part of the "tört tülik":

Toğız aq baspaq tana, Toğız aq baspaq tana işinde Jalğız tarğıl taypaqbas baspaq qana [8. 68].

Herding is a job that requires a lot of responsibility. Because he must remember not only the number of cattle, but also their color and individual characteristics. This is not an easy task. The tongue twist above is about nine white male calves and the lone hornless calf behind them. This tongue twister shows that the herdsman or cattle owner knows the cattle very well, remembers them to the smallest detail, and is meticulous.

It is known that primitive man was originally engaged in hunting. Hunting plays an important role in the life of the Turkic peoples. The reason is that in ancient times their main livelihood depended on:

Kelgen malşı

Äri änşi,

Äri añşı [8. 40].

It is said that the person who came to Tongue twister was a herdsman, but he was also a hunter who sang "añşı" - a kobiz or a drum. Kazakhs have always paid special attention to the upbringing of children. They tried to bring them up in the spirit of national values and traditions from an early age, to teach them a profession. In this regard, A.F Zeynulina and T.K Kasenova write: "The Kazakh people, who controlled their descendants to be skilled, hard-working, exemplary, noble people ... taught their son to look after cattle, to cut grass, to build barns, to make various things, to make jewelry. He taught singing, playing the drums and drums, memorizing songs, riding, singing fast, hiding riddles, waiting for guests, various national games." [9. 284]. 
Human qualities such as hospitality and respect for elders are highly valued in the Turkic peoples. Undoubtedly, the following tongue twister was created to educate the younger generation in the spirit of such qualities:

Orın berseñ kirgende,

Ülken kisi esikten Ülgili eken demey me, Üyrengen ğoy besikten [8.56].

Tongue twister expresses the philosophicaldidactic content that how a person is brought up in a family is reflected in respect for adults, upbringing begins in the family. In Turkish families, giving a guest a place in the home network or having family adults sit in the home network is one of the ancient values. This thing signifies boundless respect for the guest or parent who came, especially the father.

The Kyrgyz also stand out among the Turkic peoples with their national and spiritual traditions. Kyrgyz, like Uzbeks, Karakalpaks, and Kazakhs, have been engaged in hunting, cattle-breeding, and agriculture.

Beş arkardı

Üç mergen kwwp jönödü.

Üç mergen beș arkarga jetpey, Besh arkar üch mergenge jetkirbey,

Besh münöttö besh toonu aship, Üch mergen üch münöttö üyünö keldi [10.23].

The tongue twister quoted is about hunting, it talks about snipers and mountain goats. Most of the Kyrgyz folk sayings describe events related to hunting and animal husbandry. This suggests that the Kyrgyz also developed hunting and animal husbandry, and agriculture later.

Çoñ atamın çoñ kara bürkütün Men tomogoloboy kïm tomogolomok [10.16]. This tongue twister describes hunting-related processes. The eagle is one of the birds of prey used in hunting by the peoples of the world. From ancient times until the beginning of hunting, hunter-gatherers wore masks on their heads. This mask, that is, "Tamag'a - a mask made of leather worn on the head to cover the eyes of birds of prey" [11. 337], and this mask is worn before hunting to prevent the birds of prey from being distracted by other objects.

In Kyrgyzstan, too, tongue twister patterns, which are directly related to labor and agriculture, also make up the majority.

Ishti jaz bashinan

Bashtashibiz kerek. Jaz bashinan ishti bashtabasak,

Al ishti taptakir tashtashibiz

kerek [12. 70].

This tongue twister is created in direct connection with the labor process. It says that the work should be started in the summer, at the beginning of the summer, otherwise it should be abandoned. According to Professor B. Sarimsakov, “... in all nations, the four seasons are recognized directly, but depending on the process of labor, these four seasons are divided into two parts in some nations, and they are considered as two polar seasons, summer and winter" [13. 43]. Hence, the tongue twister expresses the philosophical content that work, especially farming, should be started in early spring, that work done after a set time, i.e., over time, is of no use, but rather harmful.

In the world, Turks stand out with their rich and colorful national ceremonies. These ceremonies, in turn, involve a variety of traditions. One such tradition is the wearing of a robe in honor of a person who has won the respect of the owner of a wedding or a feast or the country. This process is reflected in the following tongue twister: 
Kara chapan,

Atap japkan,

Aga chakan, Maga chakan,

Kana chapan,

Kara chapan [12. 89].

The color of the robe mentioned in the Tongue twister is black, and black is considered sacred in the Turks and has a positive meaning. The Russian linguist $A$. Kononov defined the meaning of the word "black" as follows: "big", "magnificent", "great", “mighty", "strong”, “pure”, “dry", "earth" ", "Dark blue ", north”[14. 161-170]. Navoi scholar I. Hakkulov noted that in ancient times the Turks had black flags, and in the past black was considered sacred in the life of the Turkic peoples. "...in ancient times, in the worldview and thought of the Turks, black had a more prominent place than white. This is why the word black has a greater place in their religious beliefs"'[15. 17-24]. The scientist Alisher Nava'i also writes that he considered black a blessed color [15. 17-24]. In Kyrgyz, black means strength, fatigue, support. So, the black robe embodies the notion of strength and health to its owner.

\section{RESULTS AND DISCUSSION}

A comparative study of the tongue twisters of the ancient Turkic peoples living on the same land allows us to draw the necessary scientific generalizations and conclusions for the folklore of both peoples. Therefore, a comparative-typological study of the tongue twisters of the Turkic peoples is relevant. Turkic peoples: study of Uzbek, Karakalpak, Kazakh and Kyrgyz expressions, comparativetypological and comparative-historical analysis, identification of historical and genetic bases of the tongue twister genre, coverage of common and peculiarities of national mentality and psyche of Turkic peoples and scientific-theoretical

substantiation allows

\section{CONCLUSION}

The ancient customs, traditions and rituals of the Turkic peoples, ie Uzbek, Karakalpak, Kazakh and Kyrgyz, who have lived side by side for a long time, have the same genetic basis and common spiritual values, are reflected in the Tongue twister. All-Turkish Tongue twisters tell about the history, lifestyle, culture, profession and occupation of the Turkic peoples. At the same time, a comparative-typological study of the Tongue twisters of the Turkic peoples will help to identify these peoples, as well as the genre of Tongue twister, its genesis, stages of historical development, social and ideological-artistic features.

\section{REFERENCES}

1. Imomov K; Mirzaev T; Sarimsoqov B; Safarov O. Oral poetry of the Uzbek people. Tashkent: Teacher, 1990.

2. Safarov O. Uzbek folk children's games. Tashkent: Sharq, 2013.

3. Sarah-Rose the rosophila. Gulsevar Gulsara. Tongue twisters from Uzbekistan translated by Rémy Dor. Paris: IFÉAC, 2005.

4. Uzbek folk art. Many roofs. Boychechak. Tashkent: Literature and Art. 1984.

5. Karakalpak folklore. Many volumes. Volumes 88-100. Nukus: Ilim. 2015.

6. Akzholova A.T Educational value and genre features of misleading // Bulletin of KazNPU named after Abai. 2012. № 2.

7. Abuova M; Satayev R. Do not be misled. Almaty: Art. 2015.

8. Nuralieva J. Kazakh misleaders. Almaty: Balausa Publishing House, 2013. 
9. Zeynulina A.F; Kassenova T.K. The nature of speech. Almaty: SSK Publishing House. 2017.

10. Tanaev T. Mistakes. Pilov. Pilov city, regional publishing house. 1999.

11. Explanatory dictionary of the Karakalpak language. Four volumes. IV. Nukus: Karakalpakstan. 1992.

12. Kapalbaev O; Kalygulov N. Kyrgyz people's mistakes. Turar, 2016.

13. Sarimsoqov B. Uzbek ceremonial folklore. Tashkent: Fan. 1986.

14. Kononov A.N. Semantics of color designations in the Turkic languages // Turkological collection. Moscow: Science, 1978.

15. Haqqulov I. More about the interpretation of black color // Uzbek language and literature. Tashkent. 2001. Issue 3.

16. https://egemen.kz/article/156999-baygedgane-onynh-turleri

17. https://ky.wikipedia.org/wiki/\%Do\%90\%D1\% 82_\%D1\%87\%D0\%Bo\%D0\%B1\%D1\%8B\%D1\%88 